\title{
PERCEIVED SUPERVISOR'S SUBCLINICAL PSYCHOPATHY, AND SUBORDINATE'S ORGANIZATIONAL COMMITMENT, JOB SATISFACTION AND SATISFACTION WITH EXECUTIVE
}

\author{
ElŻBIETA SANECKA \\ e.sanecka@wp.pl \\ University of Silesia, Poland
}

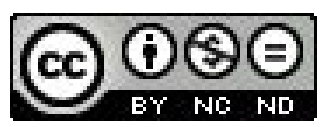

\begin{abstract}
This study was designed to investigate the correlations between supervisor's perceived subclinical psychopathy and subordinate`s organizational commitment, overall job satisfaction and particularly satisfaction with his/her supervisor. The results, based on a sample of 153 employees, showed that subordinates working with leaders, who can be defined as organizational (or industrial, corporate) psychopaths, tended to adopt more negative work attitudes. Supervisor`s perceived subclinical psychopathy had a negative impact on subordinates' job satisfaction, satisfaction with supervisor and their organizational commitment. The paper discusses the results and limitations of the study, and offers suggestions for future research.

Key words: organizational psychopath, corporate psychopath, subclinical psychopathy, personality trait, organizational commitment, job satisfaction.
\end{abstract}

\section{INTRODUCTION}

There have been a number of approaches and psychological theories of psychopathy to illuminate and understand mental disorders, such as psychopathy (Waldman, \& Rhee, 2006). However, one of the most influential and popular theories of psychopathy was established by Robert Hare $(1999,2003)$. R. Hare described psychopathy as a syndrome, a personality disorder marked by a distinctive cluster of behaviors and inferred personality traits, which together create the profile of a psychopath. According to this theory, psychopathy is defined as a combination of some core personality traits and antisocial behaviors, including glibness, irresponsibility, impulsivity, manipulation, callousness, lack of emotion, and aggression. R. Hare also developed and validated the Hare Psychopathy Checklist - Revised, an instrument that is widely used on the clinical and forensic samples. The PLC-R scores consist of two factors. The first reflects interpersonal and affective personality traits (e.g., manipulation, callousness and shallow affect); the second is related to a chronically unstable and antisocial lifestyle (e.g., criminal versatility, juvenile delinquency and poor behavior controls) (Harris, Rice, \& Quinsey, 1994).

R. Hare's psychopathy theory is well established in the clinical tradition. It describes psychopathy as a combination of inferred personality traits and socially 
deviant behaviors (Hare, \& Neumann, 2006). It is based on Hervey Milton Cleckley`s conceptualization of psychopathy, who provided the first systematic clinical account of psychopathy and identified its silent clinical features (Harris, Rice, \& Quinsey, 1994). Clinical psychopaths are usually characterized as having several typical traits and behaviors, most commonly emotional detachment, a lack of conscience, and antisocial behaviors, including irresponsibility, impulsivity and aggression (Gudmundsson, \& Southey, 2011).

Although the vast majority of previous research on psychopathy was based on criminal or clinical samples, in recent years an increased interest in noncriminal psychopathy measured in general population has been observed (Hall, \& Benning, 2006). Researchers distinguished subclinical psychopathy, whose core elements include high impulsivity and thrill-seeking, along with low empathy and anxiety (Paulhus, \& Williams, 2002). It means that subclinical psychopaths are not, qualitatively, different from their clinical counterparts (in the types or kinds of behaviors, affect, interpersonal relationships, and cognitions) in terms of their experiences. Both types, however, do differ quantitatively (in the level, intensity, or frequency) in those patterns of conduct. Clinical psychopathy assumes a specific pattern of aberrant and dysfunctional behavior, affect, and cognition that affects multiple aspects of an individual's life (work, family and social life). As a result, it turns the individual into a clinically impaired, dysfunctional employee, spouse, parent, and friend. In contrast, the subclinical psychopath is equipped with the same patterns of dysfunctional behavior, affect, and cognition, but the pervasiveness and levels of impaired functioning are not so extreme. For example, whereas the clinical psychopath might make a career only in the criminal environment, the subclinical psychopath is likely to pursue less extreme and less frequent forms of antisocial behavior, functioning equally successfully in the family, social or work sphere (Lebreton, Binning, \& Adorno, 2006). Clinical or criminal psychopathy is, in this view, seen as an extreme expression of normally distributed personality traits, of which some people have less, and some people- more. Such an view of subclinical psychopathy, which is described as a subclinical form of psychopathy, can be explained by dint of a continuum model of personality (Pethman, \& Erlandssen, 2002).

A large body of research that exists on the topic of psychopathy on non-institutionalized samples has found that there is evidence for diverse expressions of psychopathic traits across populations and that psychopathy is a dimensional construct. Researchers have identified successful psychopaths as lacking a criminal history in the general population (Falkenbach, Poythress, \& Creevy, 2008). As a result, subclinical psychopaths are sometimes described in the literature as noncriminal, nonforensic, or noninstitutionalized psychopaths. However, James Lebreton, John Binning, and Anthony Adorno (2006) recommend to use only of the terms, namely, subclinical psychopath, to avoid confusion. They justify their choice by claiming that the designation noncriminal psychopaths could refer to clinical psychopaths who have managed to avoid incarceration or who have no criminal record; alternatively, it could refer to individuals who display a pattern of behavior that is in some specific way "less severe" than their clinical counterparts. Latest research indicates that, unlike the current successful psychopaths, prototy- 
pical psychopaths are characterized by a high level of irresponsibility, impulsivity, and negligence (Mullins-Sweatt, Glover, Derefinko, Miller, \& Widiger, 2010).

Considering the clinical aspect of psychopathy (or psychopathic personality) and research concerning subclinical psychopathy, Christopher Patrick formulated an alternative theory of psychopathy. He proposed an integrative, tripartite model of psychopathy by distinguishing three phenotypic components of subclinical psychopathy: disinhibition, boldness and meanness. The first construct, disinhibition, reflects a general propensity toward impulse control problems, including carefree nonplanfulness, failure to delay gratification, irresponsibility, reactive angry emotionality, and deficient behavioral constraint. Boldness, on the other hand, represents the nexus of social dominance, low stress reactivity, and thrill-adventure seeking/ fearlessness. It can be traced back to H. M. Cleckley's and David Lykken's descriptions of psychopathy. Finally, meanness is defined as aggressive resource seeking without regard for others ("dysaffliated agency") and can be best characterized as a phenotypic manifestation of reduced empathic responding, callousness, exploitativeness, empowerment through cruelty, inability to form close attachments with others, and excitement seeking. These three phenotypic constructs are the key to understanding psychopathy in its varying manifestations: criminal and noncriminal; primary and secondary; stable and aggressive; unsuccessful and successful (Patrick, Fowles, \& Krueger, 2009; Sellbom, \& Phillips, 2012). The present study makes use of C. Patrick`s conceptualization of psychopathy.

\section{THE CORPORATE PSYCHOPATH}

The adaptation of psychopathy to the subclinical sphere is not a novelty. In 1941, H. M. Cleckley (1988) published a classic monograph Mask of Sanity, in which he established a set of diagnostic criteria for psychopathy and proposed an etiological model of the disorder. The book also referred to incomplete manifestations or symptoms of the disorder. H. M. Cleckley presents case studies of psychopathic individuals who managed to achieve and maintain successful functioning in the community (e.g., as businessmen, scientists, physicians, psychiatrists). He views such "successful" cases as alternative manifestations of the same underlying pathology, which means that the ability to function successfully within society indicates a subclinical condition (Patrick, 2006).

Since the publication in 2003 of Paul Babiak and Robert Hare`s book Snakes in Suits: When Psychopaths go to Work, there has been growing interest in the phenomenon of successful "corporate psychopaths", or psychopathic individuals functioning in the work environment. A successful corporate psychopath have also been called, on the one hand, an executive, industrial or organizational psychopath, and organizational sociopath, on the other. That kind of psychopath is usually defined as a psychopath who works and acts within an organizational area and exhibits a subclinical manifestation of psychopathic traits. The corporate psychopath has not been incarcerated in the judicial or mental health systems, and is more likely to engage in manipulative and antisocial behavior (Gudmundsson, \& Southey, 2011; Boddy, 2011). 
These organizational psychopaths can be extremely destructive to the organizations for which they work. They may be responsible for and involved in many breaches of law, including accounting fraud and stock manipulation. Moreover, they are able to present themselves as desirable employees and are easily able to obtain managerial positions in organizations. Without the inhibiting effect of their conscience, they are capable of ruthlessly charming, lying and manipulating their supervisors and coworkers in order to work their way up through an organizational hierarchy in pursuit of their main aims of power, wealth and status (Boddy, 2006; Babiak, \& Hare, 2006; Boddy, 2010). Recent research indicates that they are also poorly organized managers who have a negative impact on many different areas of organizational effectiveness and productivity (Babiak, 2007; Boddy, 2011). The consequences of industrial psychopathic behavior (especially on managerial positions) are extreme, both financially (for the organizations) and emotionally (for their coworkers and subordinates). It thus seems important to understand this dark side of leadership (Gudmundsson, \& Southey, 2011).

\section{JOB SATISFACTION}

The traditional definition of job satisfaction was proposed by Edwin Locke (1976, p. 1304), who in his Handbook of Industrial Psychology described job satisfaction as "a pleasurable or positive emotional state resulting from the appraisal of one's job or job experiences". Such an understanding of job satisfaction as a social attitude is most commonly used in organizational research (Judge, \& Klinger, 2007) and reflects the importance of both affect, or feeling, and cognition, or thinking. Cognition and affect are linked both in our psychology and even in our biology. Thus, both thinking and feeling are crucial when evaluating our jobs (Saari, \& Judge, 2004).

The distinction between cognitive and affective aspects of job satisfaction is widely accepted in the literature. Howard Weiss (2002) points out that attitudes as evaluative judgments about objects are important and might be easily measured with descriptive scales. However, the positive and negative moods, as well as emotions and affects connected with job, are conceptually distinct from evaluation concerning job. As a result, using the same measures to assess cognitive judgments and affects, we can misunderstood what we are assessing while measuring job satisfaction.

In this study we distinguish cognitive and affective aspects of job satisfaction, using two separate instruments to measure the level of subjective satisfaction at work. Furthermore, we assess both overall job satisfaction and particularly satisfaction with subordinates. This attitude is consistent with the most typical conceptualization of job satisfaction in empirical papers as a global concept that is comprised of, or indicated by, various facets, including: pay, promotions, coworkers, supervision, and the work itself. Researchers also consider job satisfaction in terms of its extrinsic and intrinsic elements. For example, pay and promotions are considered extrinsic factors and coworkers, supervision, and the work itself are considered intrinsic factors (Judge, \& Klinger, 2007). 


\section{ORGANIZATIONAL COMMITMENT}

Organizational commitment is the second most popular (after job satisfaction) work attitude in the literature (Jachnis, 2008). It denotes the attachment of employees to the organization and is differentiated from job involvement, with the former referring to the individual's level of psychological identification with the specific job in which he or she is engaged. These two forms of work commitment may interact in the prediction of job-related outcomes, but it has been pointed out that job involvement shows higher associations with performance, while organizational commitment is more related to other variables, such as absence and turnover. Recent studies in the field of work and organizational psychology have drawn distinctions between various dimensions of organizational commitment (O'Driscoll, \& Randall, 1999). Also, it has been proposed that commitment can take up different forms, and that the antecedents, consequences, and correlates of every form will be somewhat different (Meyer, Irving, \& Allen, 1998).

One of the most popular theoretical approaches to organizational commitment is John Meyer and Natalie Allen's (1991) Three-Component Model. Their framework assumes that organizational commitment is treated as a multidimensional construct. J. Meyer and N. Allen (1991, p. 67) define organizational commitment as "a psychological state that characterizes the employee`s relationship with the organization, and has implications for the decision to continue or discontinue membership in the organization". The scholars distinguish three separate components of organizational commitment: affective, continuance, and normative commitment. Affective commitment is defined as an employee`s emotional attachment to, identification with, and involvement in the organization. Continuance commitment is understood as an awareness of costs associated with leaving the organization. Finally, normative commitment can be described as a sense of duty to maintain employment.

Further research indicates that the three forms of commitment are related. Simultaneously, they are distinguishable from one another as well as from job satisfaction, job involvement, and occupational commitment (Meyer, Stanley, Herscovitch, \& Topolnytsky, 2002). It has been proved that affective and continuance commitment should be differentiated, both theoretically and empirically. These two components of organizational commitment have distinct underlying foundations. In the vast majority of research, there has been observed a near-zero correlation between them (O'Driscoll, \& Randall, 1999). However, the recent empirical criticism on the Three-Component Model of Organizational Commitment concentrates on the position of continuance commitment as a dimension of the overall commitment construct. Continuance commitment slightly negatively or not at all correlates with affective commitment, important affective or attitudinal correlates, and work-related outcome variables, such as organizational citizenship behaviors and job performance. Moreover, in different studies normative commitment has consistently been found to correlate very strongly with affective commitment. As a result, it is hard to separate normative commitment from affective commitment empirically (Solinger, van Olffen, \& Roe, 2008). In the present study we took into account previous results concerning the relations and differences between continuance, normative and affec- 
tive commitment. Our hypothesis was that supervisor's perceived organizational psychopathy would be related to affective and normative commitment, but not to continuance component of the Three-Component Model.

\section{RESEARCH METHOD}

\section{Purpose and hypotheses}

The purpose of the present study is to examine the influence of supervisor's perceived subclinical psychopathy on subordinate`s job satisfaction, satisfaction with supervisor and affective, continuance, and normative commitment to the organization by measuring the work attitudes and perception of manager's personality traits among employees. During the study the subordinates expressed their personal, subjective opinions about their supervisors.

The expected relationship between supervisor`s subclinical psychopathy and employee`s organization commitment and job satisfaction is based on research carried out in numerous previous studies concerning the perception of leadership and employee`s work attitudes (e.g., Lok, \& Craford, 1999; Lok, \& Craford, 2001; Dirks, \& Ferrin, 2002; Lok, \& Craford, 2004). According to these findings, those who perceive their superiors as adopting consultative or participative leadership styles are more committed to their organizations, more satisfied with their jobs, and their performance is higher (Yousef, 2000). The results of research conducted by Soonhee Kim (2002) show that managers' use of a participative management style and employees' perceptions of participative strategic planning processes are positively correlated with employees' job satisfaction. Other findings indicated a strong relationship between supervisors' task and relational leadership styles and job satisfaction (Madlock, 2008). Also, it has been suggested that employees' perception of their level of empowerment are strongly related to their evaluations of job satisfaction and organizational commitment (Wu, \& Short, 1996, Liden, \& Wayne, Sparrowe, 2000).

However, previous research suggested that the leadership style of industrial psychopaths is negatively perceived by their subordinates. Paul Babiak, Craig Neumann and Robert Hare (2010) pointed out, that psychopathy is strongly correlated with poor management style, failure to act as a team player, and poor performance appraisals, rated by immediate bosses. Moreover, according to further studies psychopathy positively correlated with passive management-by-exception and laissez-faire, and, at the same time, negatively correlates with individual consideration (Westerlaken, \& Woods, 2013). These results indicate that organizational psychopaths on managerial positions might prefer a less participative leadership style and support empowerment in the workplace. Also, it has been suggested that the presence of managers who are classified as industrial psychopaths negatively affects a corporation's levels of perceived corporate social responsibility, good communications and employees`commitment. Simultaneously, the levels of conflict and organizational constraints go up (Boddy, 2012), which can lower an employee`s job satisfaction.

Below are specific hypotheses to be tested in the study : 
Hypothesis 1: Perceived supervisor`s subclinical psychopathy is negatively related to subordinate`s job satisfaction, both in its cognitive and affective aspect.

We have decided to distinguish two separate aspects of job satisfaction, which reflects the most widely methods used in measuring this variable in organizational behavior. One refers to the cognitive component of this work attitude. It is defined as a positive or negative judgment one makes about one`s job or job situation. We also measured the affective component of job satisfaction, which is related to the positive or negative feelings, moods and emotions of an employee (Zalewska, 2001). As a result, we assumed that supervisors`subclinical psychopathy is negatively related to the positive mood at work, and, simultaneously, is positively correlated with the negative mood in the work environment.

Previous research indicates that psychopathy in the organizational environment is positively associated with workplace aggression and counterproductive behavior, unethical decision-making and white-collar crimes (Smith, Lilienfeld, 2013). Clive Boddy (2006) suggested that organisational psychopaths may be responsible for many breaches of law, including accounting fraud and stock manipulation. Moreover, their harmful and unethical behaviour, including manipulation, bullying and unfair supervision, may be directed toward their subordinates and co-workers (Boddy, 2010; Boddy, 2011), which, in turn, may affect employees overall job satisfaction.

Hypothesis 2: Supervisor's perceived subclinical psychopathy is negatively related to subordinate`s particularly satisfaction with supervisor.

In the study we distinguished one of the facets of job satisfaction, namely, employee satisfaction with supervisor. In doing so, the study follows the discussion in the field of work and organizational psychology of the relationship between overall satisfaction and facet satisfaction. According to Howard Weiss (2002), there are some discriminable objects in the work environment that we evaluate. They reflect different aspects of our work experience, for instance, relations with supervisor or co-workers.

Previous research indicates that the presence of corporate psychopaths in a workplace to a great degree correlates with bullying and employees ' perceptions of unfair and disinterested supervision (Boddy, 2010). Corporate psychopaths are also described as unethical decisions-makers (Stevens, Deuling, \& Armenakis, 2011). In consequence, an executive who has a high level of subclinical psychopathy may be perceived as less participative and supportive, which, in turn, causes his/her employees to feel much less satisfied with their supervisor.

Hypothesis 3: Supervisor's perceived subclinical psychopathy is negatively related to subordinate's overall organizational commitment and affective and normative commitment, but not to continuance commitment.

The assumption that there is no significant correlation between perceived supervisor`s subclinical psychopathy and employee`s continuance commitment stems from the analysis of J. Meyer and N. Allen's Three-Component Model of Organizational Commitment. Continuance commitment is more calculative than affective and normative commitment. It is determined by perceived costs and benefits of organizational membership, and reflects the tendency to remain in the orga- 
nization resulting from a recognition of the costs associated with its termination (Meyer, \& Allen, 1991). As a result, continuance commitment is contingent on external, situational conditions of a workplace environment rather than on internal factors, including personality traits of an executive, i.e. subclinical psychopathy.

Most previous studies on corporate psychopaths, have highlighted the negative influence of corporate psychopaths on their organizational environment, subordinates and co-workers (e.g., Babiak, 1995; Boddy, 2006; Babiak, Neumann, \& Hare, 2010; Mullins-Sweatt, Glover, Derefinko, Miller, \& Widiger, 2010). The research conducted by Clive Boddy, Richard Ladyshewsky and Peter Galvin (2010) has evinced a strong negative influence that the presence of corporate psychopaths has both on the perception of corporate social responsibility and on organizational commitment to employees within organizations. Moreover, employees working under industrial psychopaths felt that they did not receive due recognition for doing a good job, that their work was not appreciated and that their efforts were not properly rewarded. It goes without saying that the presence of corporate psychopaths in an organization can negatively affect commitment and identification with organization. Also, when corporate psychopaths are present in a work environment, the level of bullying is significantly greater and supervisors are regarded as being unfair to employees and indifferent to their feelings (Boddy, 2010), which, in turn, can result in lower organizational commitment and job satisfaction.

\section{MEASURES}

Five reliable scales (or subscales) have been used for our survey. These included Triarchic Psychopathy Measure (TriPM) by Christopher Patrick, Life Satisfaction Questionnaire, Job Affect Scale, Job Satisfaction Questionnaire by Oswald Neuberger and Mechthild Allerbeck, Organizational Commitment Scales (OCS) by John Meyer and Natalie Allen. Coefficient alpha Cronbach reliability estimates for this study are shown in Table 2.

Subclinical psychopathy. We measured leaders`subclinical psychopathy as perceived by subordinates using the Triarchic Psychopathy Measure (TriPM), which is based on C. Patrick`s triarchic conceptualization of psychopathy (Patrick, 2010). The TriPM is a 58-item self-report measure of psychopathy. It consists of three scales that capture distinct constructs of Meanness (19 items), Boldness (19 items), and Disinhibition (20 items). On a 4-point, Likert-type scale respondents decide to what degree of the listed personal characteristics apply to them (mostly false, false, mostly true, true) (Stanley, Wygant, \& Sellbom, 2012).

Job satisfaction. Using two different scales, we measured two aspects of job satisfaction (cognitive and affective).

We assessed the cognitive aspect of job satisfaction on the subscale of Life Satisfaction Questionnaire FLZ (Fragebogen zur Lebenszufriedenheit), formulated by Jochen Fahrenberg, Michael Myrtek, Jőrg Schumacher and Elmar Brahler, and translated into Polish by Jan Chodkiewicz (2009). The FLZ questionnaire is a 70item instrument designed to measure global life satisfaction. It can also be used to assess life satisfaction in ten separate fields, including health, professional life, 
financial situation, leisure and hobbies, marriage/partnership, relationship to one's own children, self-esteem, sexuality, social life, and living situation. In the present study, we used the 'Professional life` scale to evaluate one's cognitive judgments of job satisfaction. Respondents were asked to evaluate given statements on a 7-point Likert scale, ranging from "Extremely satisfied" to "Extremely dissatisfied."

We measured the affective aspect of job satisfaction on the 12-item version of Job Affect Scale (JAS). This instrument is commonly used and widely recognized as a tool to measure the degree of positive and negative mood in the workplace. In the study for each statement employee indicated how the respondents felt during the past month on a scale that ranged from "very slightly or not at all" (1) to "extremely" (5). To measure positive affects at work, we used six items: active, strong, enthusiastic, peppy, elated, sluggish (reverse scored). We measured the level of negative mood using the six items from JAS, including: distressed, scornful hostile, fearful, at rest (reverse scored), nervous, jittery (Madjar, Oldham, \& Pratt, 2002).

Satisfaction with supervisor. To measure this type of satisfaction, we used one of the scales from Job Satisfaction Questionnaire by Oswald Neuberger and Mechthild Allerbeck, which was translated into Polish by Anna Zalewska (2001). The scale, called "Supervision/Supervisor", is comprised of 12 statements that describe the immediate supervisor of the respondent. Each statement is rated on a 4-point, descriptive scale (mostly false, false, mostly true, true). The instrument can also be used to measure the total satisfaction of a manager on a graphical, facial scale.

Organizational commitment. To measure commitment we used the Organizational Commitment Scales (OCS), which was designed by Natalie Allen and John Meyer and adapted into Polish by Augustyn Bańka, Agata Wołoska and Róża Bazińska (2002). In its first version, it is made up of the 8-item Affective (ACS), Continuance (CCS), and Normative (NCS) Commitment Scales and is utilized to measure the three dimensions of organizational commitment identified by N. Allen and J. Meyer (1990): affective, continuance, and normative. Affective commitment reflects employees' emotional attachment to, identification with, and involvement in, the organization. Continuance commitment involves a recognition of the costs associated with leaving the organization. The third form of organizational commitment, normative commitment, stands for employees' feelings of obligation to remain with the organization (Meyer, Irving, \& Allen, 1998). The authors of the Organizational Commitment Scales, N. Allen and J. Meyer (1996), provided clear evidence for the satisfactory validity of these measures. The Polish version of the Organizational Commitment Scales (OCS) contains 18 forced-choice items. Each form of organizational commitment (affective, continuance, and normative) is measured by six items. All responses are measured on a 7-point Likert scale, ranging from "I strongly disagree" to "I strongly agree." The Polish version of OCS has satisfactory psychometric characteristics. Its three scales showed satisfactory internal consistency (from .84 to .77) as well as validity (Bańka, Wołoska, Bazińska, 2002). 


\section{PROCEDURE}

The questionnaire included demographic information and measures of how the participants perceived leaders`subclinical psychopathy affects their organizational commitment, job satisfaction and satisfaction with supervisor. In the study the employees were asked whether they could perceive any symptoms of their supervisor`s subclinical psychopathy. We modified the instructions in the Christopher Patrick`s Triarchic Psychopathy Measure (TriPM). The respondents were asked to evaluate how well each statement included in the questionnaire reflected the behaviors of their managers or to choose the option that best describes their supervisor. We also adopted some statements in TriPM, e.g. in the first statement we used the phrase "He (she)'s optimistic more often than not." instead "I'm optimistic more often than not."

We conducted a pilot study based on 12 returned questionnaires. It includes questions that ask about the opinions of competent judges, who evaluated the clarity of instructions and each of the questions included in the questionnaire. The results of the pilot study showed that only a few changes were necessary for the questionnaire to be used in the main study. It occurs that all participants had no difficulties in understanding the instructions and questions included in the questionnaire.

For our main study, we used snowball sampling, which is a non-probability sampling technique used to gather information from a specific population. Each participant had to meet two criteria required by the study protocol: they must have an employment status and work under at least one immediate supervisor. Data were being collected over a 6-week period (in March and April 2012) from employees living in the Silesia province in Poland. Copies of the survey were sent off to 30 employees by email, and 140 questionnaires were distributed in paper form. 156 questionnaires were recovered, and 153 fully completed and used in the final data analysis, which gave the response rate of 91.76 percent. The participation in the study was voluntary. All employees were granted anonymity. This information was also provided together with the instructions attached to the study. The final survey consisted of two parts. The first one, entitled "Your supervisor", concerned perceived subclinical psychopathy of the manager. The respondents were asked to evaluate how their executive would behave or what he would think in a given situation. In the second part of the survey the participants were asked to describe the level of their job satisfaction, satisfaction with executive and organizational commitment.

\section{SAMPLE}

The final sample consisted of 153 employees working in different sectors and branches. All research participants were employed and had at least one immediate supervisor. 45 of them were male $(29.41 \%)$ and 108 female $(70.59 \%)$ aged $19-60$. The mean age of the sample was 33. The majority of respondents (50.33\%) were between 19 and 30. They came from a wide variety of industries (telecommunications, accounting, banking, education, retail and others). We observed the variability of the respondents` hierarchical level. The vast majority of employees (77.12\%) 
held non-executive positions. Other respondents were junior executives (19.61\%) and senior executives (3.27\%). The average work experience was 11 years, ranging from 2 months to 40 years. The majority of participants were married $(59.17 \%)$, 33.22 percent were single and 2.61 percent divorced. A demographic structure of the sample is presented in Table 1.

Table 1. A structure of the sample

\begin{tabular}{|l|l|c|c|}
\hline \multicolumn{1}{|c|}{ Characteristics } & \multicolumn{1}{|c|}{ Level } & Frequency & Percent \\
\hline Sex & Female & 108 & 70.59 \\
& Male & 45 & 29.41 \\
\hline Marital status & Married & 60 & 58.17 \\
& Single & 89 & 39.22 \\
& Divorced & 4 & 2.61 \\
\hline The knowledge of & Very good & 1 & 0.65 \\
supervisor & Good & 130 & 84.97 \\
& Neither good or bad & 16 & 10.46 \\
& Bad & 6 & 3.92 \\
& Very bad & 0 & 0 \\
\hline Position & Non-executive & 118 & 77.12 \\
& Junior executive & 30 & 19.61 \\
& Senior executive & 5 & 3.27 \\
\hline Age & 19 years - 30 years & 77 & 50.33 \\
& 30 years - 40 years & 38 & 24.84 \\
& 40 years - 50 years & 18 & 11.76 \\
& 50 years - 62 years & 20 & 13.07 \\
\hline Work experience & 2 months - 10 years & 91 & 59.48 \\
& 10 years - 20 years & 31 & 20.26 \\
& 20 years - 30 years & 10 & 6.54 \\
& 30 years - 40 years & 21 & 13.72 \\
\hline In total & & $\mathbf{1 5 3}$ & $\mathbf{1 0 0}$ \\
\hline
\end{tabular}

Source: Author

The respondents were also asked to evaluate how well they knew their subordinates on the 5-piont, Lykert-type scale. 130 of them $(84.97 \%)$ declared that they know their subordinates well. Only 16 respondents (10.46\%) described their familiarity with their manager as neither good or bad. Six employees assessed it as very bad, and only one as very good.

\section{RESULTS}

All statistical analyses were conducted using the STATISTICA program, version 10. To examine the relationship between perceived leader subclinical psychopathy and employee work attitudes, such as organizational commitment, job satisfaction and satisfaction with executive, several analyses were conducted. Descriptive statistics and reliability analyses were conducted on all study variables. Correlations between the major variables of the study were calculated. Regression 
analyses were used to examine the extent to which the respondents' work attitudes, such as organisational commitment and job satisfaction, can be predicted from the perceived leaders`subclinical psychopathy.

\section{DESCRIPTIVE RESULTS}

In the study, we calculated Cronbach alpha reliability estimates for each scale used in the study and descriptive measures, such as arithmetic mean, standard deviation, skewness and kurtosis. Coefficient Cronbach alpha reliability estimates, descriptive results and results of Kolomogorow-Smirnov test for normality obtained in the study are reported in Table 2.

Table 2. Descriptive measures and reliability $(\mathrm{N}=153)$

\begin{tabular}{|c|c|c|c|c|c|c|c|}
\hline \multirow[t]{2}{*}{ Variable } & \multirow[t]{2}{*}{$\mathbf{M}$} & \multirow[t]{2}{*}{ SD } & \multirow{2}{*}{$\begin{array}{l}\text { Skew- } \\
\text { ness }\end{array}$} & \multirow{2}{*}{$\begin{array}{l}\text { Kurto- } \\
\text { sis }\end{array}$} & \multirow{2}{*}{$\begin{array}{l}\text { Alfa } \\
\text { Cron- } \\
\text { bacha }\end{array}$} & \multicolumn{2}{|c|}{$\begin{array}{c}\text { Kolmogorov- } \\
\text { Smirnow } \\
(\mathrm{df}=153)\end{array}$} \\
\hline & & & & & & $\begin{array}{l}\text { Statis- } \\
\text { tics }\end{array}$ & $\begin{array}{c}\text { Signifi- } \\
\text { cance }\end{array}$ \\
\hline $\begin{array}{l}\text { Subclinical } \\
\text { psychopathy }\end{array}$ & 75.326 & 19.171 & 0.499 & 0.133 & 0.900 & 0.075 & $p<.05$ \\
\hline$>$ Boldness & 31.600 & 6.659 & -0.144 & -0.033 & 0.760 & 0.055 & $p>.20$ \\
\hline$>$ Meanness & 23.907 & 11.127 & 0.438 & -0.191 & 0.930 & 0.076 & $p<.05$ \\
\hline$>$ Disinhibition & 19.818 & 9.722 & 0.664 & -0.164 & 0.900 & 0.101 & $p<.01$ \\
\hline $\begin{array}{l}\text { Satisfaction from } \\
\text { supervisor } \\
\text { (descriptive scale) }\end{array}$ & 35.140 & 7.724 & -0.587 & -0.206 & 0.920 & 0.104 & $p<.01$ \\
\hline $\begin{array}{l}\text { Satisfaction from } \\
\text { supervisor } \\
\text { (graphical scale) }\end{array}$ & 4.704 & 1.476 & -0.646 & 0.180 & - & 0.181 & $p<.01$ \\
\hline $\begin{array}{l}\text { Organizational } \\
\text { commitment }\end{array}$ & 66.972 & 21.351 & -0.075 & -0.477 & 0.900 & 0.066 & $p<.10$ \\
\hline $\begin{array}{l}\text { Normative } \\
\text { commitment }\end{array}$ & 20.888 & 9.012 & -0.066 & -0.923 & 0.660 & 0.093 & $p<.01$ \\
\hline $\begin{array}{r}\text { Continuance } \\
\text { commitment }\end{array}$ & 23.484 & 7.327 & -0.075 & -0.301 & 0.860 & 0.068 & $\mathrm{p}<.10$ \\
\hline $\begin{array}{l}\text { Affective } \\
\text { commitment }\end{array}$ & 22.600 & 8.367 & -0.089 & -0.759 & 0.840 & 0.080 & $p<.05$ \\
\hline Negative mood & 15.724 & 4.494 & 0.083 & -0.426 & 0.740 & 0.087 & $p<.01$ \\
\hline Positive mood & 20.092 & 4.061 & -0.525 & 0.350 & 0.750 & 0.086 & $p<.01$ \\
\hline \begin{tabular}{|l}
$\begin{array}{l}\text { Job satisfaction } \\
\text { (cognitive aspect) }\end{array}$ \\
\end{tabular} & 31.352 & 8.016 & -0.585 & 0.079 & 0.850 & 0.087 & $p<.01$ \\
\hline
\end{tabular}

Source: Author

The Cronbach alpha reliability estimates presented in Table 2 for subclinical psychopathy, job satisfaction and organizational commitment variables demonstrated satisfactory reliability. Cronbach's coefficient alpha for all scales (except 
for Normative Commitment Scale) was more than 0.7 . The reliability estimates are also generally comparable in magnitude with the values found in previous studies dealing with work attitudes and subclinical psychopathy (Bańka, Wołoska, \& Bazińska, 2002).

The mean value for the cognitive aspect of job satisfaction was lower in the present study than in Jan Chodkiewicz's study (2002). It means that the study respondents were less satisfied with their job than the employees from Polish general population. A similar tendency has been observed in relation to supervisor satisfaction, which was measured on a 1-item graphical scale (Zalewska, 2001), and organizational commitment (Bańka, Wołoska, \& Bazińska, 2002).

The skewness analysis showed that variables such as boldness, satisfaction from supervisor, organizational commitment, cognitive aspect of job satisfaction and positive feelings toward job had right skewed distribution. The kurtosis analysis indicated that the majority of variables have a sharper or flatter distribution than a normal distribution. We also conducted a nonparametric KolmogorovSmirnov test to verify the normality of variables' distribution. The distribution analysis showed that only boldness, overall organizational commitment and continuance commitment had a normal distribution.

\section{CORRELATIONS}

To test the formulated hypotheses, we conducted correlation analyses. We used Spearman's rank correlation coefficient, one of the most popular nonparametric measure of statistical dependence between two variables, because the majority of variables do not have a normal distribution. The correlations amongst the main variables in the study are shown in Table 3.

Table 3. Correlations in the sample

\begin{tabular}{|l|c|c|c|c|}
\hline \multirow{2}{*}{ Variable } & \multicolumn{3}{c|}{ Subclinical psychopathy } \\
\cline { 2 - 5 } & Overall & Boldness & Meanness & Disinhibition \\
\hline $\begin{array}{l}\text { Satisfaction with supervisor } \\
\text { (descriptive scale) }\end{array}$ & $-0.662^{* *}$ & $0.333^{* *}$ & $-0.773^{* *}$ & $-0.650^{* *}$ \\
\hline $\begin{array}{l}\text { Satisfaction with supervisor } \\
\text { (graphical scale) }\end{array}$ & $-0.521^{* *}$ & $0.266^{* *}$ & $-0.627^{* *}$ & $-0.502^{* *}$ \\
\hline Organizational commitment & $-0.223^{* *}$ & -0.037 & $-0.248^{* *}$ & -0.111 \\
\hline$>$ Normative commitment & $-0.193^{*}$ & -0.015 & $-0.272^{* *}$ & -0.064 \\
\hline$>$ Continuance commitment & -0.050 & -0.066 & 0.003 & -0.028 \\
\hline$>$ Affective commitment & $-0.285^{* *}$ & 0.009 & $-0.310^{* *}$ & $-0.180^{*}$ \\
\hline Negative mood & $0.395^{* *}$ & -0.145 & $0.451^{* *}$ & $0.297^{* *}$ \\
\hline Positive mood & $-0.293^{* *}$ & 0.134 & $-0.369^{* *}$ & $-0.232^{* *}$ \\
\hline $\begin{array}{l}\text { Job satisfaction } \\
\text { (cognitive aspect) }\end{array}$ & $-0.391^{* *}$ & $0.165^{*}$ & $-0.454^{* *}$ & $-0.307^{* *}$ \\
\hline
\end{tabular}

Notes: $\mathrm{N}=153 ;{ }^{*} \mathrm{p}=0.05$ and ${ }^{* *} \mathrm{p}=0.01$.

Source: Author 
We found relatively low negative correlations of less than 0.30 between a supervisor`s meanness and his/her overall, normative and affective commitment. There was no significant correlation between the supervisor's subclinical psychopathy and continuance commitment. It partially confirms Hypothesis 1 , according to which the supervisor`s perceived subclinical psychopathy is negatively related to the subordinate`s overall organizational commitment and its two forms - affective and normative commitment, but not to continuance commitment.

The results presented in Table 3 indicated that the strongest correlations occurred between overall perceived supervisor`s subclinical psychopathy (and its two dimensions - meanness and disinhibition) and facet satisfaction with manager. We noted a weak positive link between bold leadership and employee satisfaction with manager $(r=0.33$ for descriptive scale, and $r=0.29$ for graphical scale), which was incompatible with our predictions. The results of the study partially confirm hypothesis 2 , according to which perceived supervisor's subclinical psychopathy is negatively related to subordinate`s satisfaction with supervisor.

As expected, we confirmed hypothesis 3, according to which perceived supervisor`s subclinical psychopathy will be negatively related to subordinate`s job satisfaction, both in terms of its cognitive and affective aspect. Correlations ranging from -0.165 to -0.454 were observed between supervisor`s overall subclinical psychopathy, boldness, meanness, disinhibition and employee job satisfaction measured in the cognitive aspect. The negative correlation of bold leadership with the cognitive aspect of job satisfaction was small, but statistically significant. We also noted that perceived supervisors'subclinical psychopathy, meanness and disinhibition were negatively related to positive mood at work, and positively to negative mood in the work environment. There was no statistically significant correlation between manager`s boldness and affective aspect of employee`s job satisfaction.

The correlation analysis confirmed hypothesis 3, and partially validated hypothesis 1 and 2. More importantly, these findings point to a connection between perceived leader`s subclinical psychopathy and employee`s organizational commitment, job satisfaction and satisfaction with supervisor.

\section{REGRESSION ANALYSES}

Regression analysis was used to evaluate the influence of a leader's perceived subclinical psychopathy on organizational commitment of subordinates, their overall job satisfaction and facet satisfaction from supervisor. In other words, regression analysis was used to investigate the prediction of job satisfaction, satisfaction with supervisor and organizational commitment on the basis of the perceived supervisor's subclinical psychopathy and its dimensions. Table 4 presents the simple linear regression models for the prediction of employee work attitudes. 
Table 4. The simple linear regression models: the effect of perceived supervisor`s subclinical psychopathy on subordinate`s organizational commitment, job satisfaction and satisfaction with executive

\begin{tabular}{|c|c|c|c|c|c|c|c|}
\hline \begin{tabular}{|l}
$\overline{\mathrm{g}}$ \\
$\overline{\mathrm{z}}$ \\
$\bar{\Sigma}$
\end{tabular} & Variable & B & $\mathbf{R}$ & $\mathbf{R}^{2}$ & 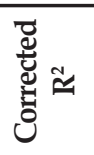 & $\begin{array}{l}\mathrm{F}(1, \\
151)\end{array}$ & p \\
\hline 1 & Organizational commitment & -0.233 & 0.209 & 0.044 & 0.037 & 6.880 & 0.010 \\
\hline 2 & $>$ Normative commitment & -0.094 & 0.200 & 0.040 & 0.033 & 6.266 & 0.013 \\
\hline 3 & $>$ Continuance commitment & -0.024 & 0.062 & 0.004 & -0.003 & 0.585 & 0.445 \\
\hline 4 & $>$ Affective commitment & -0.115 & 0.263 & 0.069 & 0.063 & 11.249 & 0.001 \\
\hline 5 & Job satisfaction (cognitive aspect) & -0.163 & 0.390 & 0.152 & 0.146 & 27.007 & 0.000 \\
\hline 6 & Negative mood & 0.084 & 0.357 & 0.127 & 0.121 & 21.988 & 0.000 \\
\hline 7 & Positive mood & -0.065 & 0.306 & 0.094 & 0.088 & 15.579 & 0.000 \\
\hline 8 & $\begin{array}{l}\text { Satisfaction with supervisor } \\
\text { (descriptive scale) }\end{array}$ & -0.273 & 0.684 & 0.467 & 0.464 & 129.770 & 0.000 \\
\hline 9 & $\begin{array}{l}\text { Satisfaction with supervisor } \\
\text { (graphical scale) }\end{array}$ & -0.042 & 0.544 & 0.296 & 0.292 & 63.580 & 0.000 \\
\hline
\end{tabular}

Source: Author

In all presented regression equations, we used perceived supervisor`s subclinical psychopathy as a predictor of subordinate employees' work attitudes. The variable referring to manager's personality trait has no significant effect only on employee`s continuance commitment $(\mathrm{p}=0.445)$. This result correspondents with the previous analysis of the construct of organizational commitment and confirms hypothesis 3 . Interactions between leadership personality variable on overall organizational commitment and its two dimensions - normative and affective commitment - were statistically significant $(\mathrm{p}<0.01)$. However, the explanatory variable - perceived supervisor`s subclinical psychopathy - explains only a small percentage of the variance of employee`s organizational, normative and affective commitment (respectively, 3.7\%, 3.3\% and 6.3\%).

We noted a similar, yet not identical, pattern of results in the regression equations for the prediction of job satisfaction. The supervisor`s perceived subclinical psychopathy had a significant negative effect on the cognitive component of job satisfaction (corrected $\mathrm{R}^{2}=0.146, \mathrm{p}<0.01$ ), indicating that $14.6 \%$ variance of the dependable variable (cognitive aspect of job satisfaction) can be accounted for the explanatory variable - leader`s subclinical psychopathy. Interactions between supervisor`s perceived subclinical psychopathy and affective component of subordinate's job satisfaction were also significant. They confirmed hypothesis 1. An examination of models 6 and 7 shows a statistically significant positive effect for the explanatory variable on negative mood in the workplace and negative effect on positive mood at work.

The leadership personality variable had also a significant negative effect on employee satisfaction with supervisor, confirming hypothesis 2 and indicating 
that people subordinated to industrial psychopaths report lower levels of facet satisfaction. The corrected $\mathrm{R}^{2}$ for the sample indicates that the effect of perceived leader's subclinical psychopathy was stronger (more negative) when satisfaction with supervisor in particular was measured by means of a descriptive scale instead of the 1-item, graphical one. More specifically, the findings indicated that the supervisor's psychopathy accounted for $46.4 \%$ of the variance in subordinate satisfaction from supervisor measured on the descriptive scale and $29.2 \%$ assessed on the graphical scale.

\section{DISCUSSION}

The influence of the presence of organizational psychopath on employee work attitudes has not been investigated so far. Based on a sample of 153 employees, the present study aimed to examine the effect of corporate subclinical psychopathy on employees' organizational commitment, their overall job satisfaction and, most importantly, satisfaction with supervisor. The results revealed the statistically significant negative effect of the leadership personality variable on employees' work attitudes. This is consistent with previous studies, indicating a strong link between a leadership style, job satisfaction and organizational commitment (Lok, \& Crawford, 1999; Yousef, 2000; Dirks, \& Ferrin, 2002; Lok, \& Crawford, 2004) and suggesting that the presence of corporate psychopaths negatively affects employees' work attitudes, such as organizational commitment and job satisfaction (Babiak, 1995; Boddy, 2005; Boddy, 2010; Boddy, 2012).

The results of the present study showed that it is satisfaction with supervisor rather than the cognitive and affective components of overall job satisfaction that is more determined by the leadership personality trait variable. The correlation and regression analysis indicated that perceived subclinical psychopathy of supervisors and its two dimensions (meanness and disinhibition) were strongly linked to satisfaction with supervisor. The observation suggests that leader`s subclinical psychopathy plays an important role as an antecedent of satisfaction with manager and affects the level of overall job satisfaction. These findings are consistent with the results of previous research, indicating that executive's personality traits and behaviors can influence job satisfaction of their followers (Podsakoff, MacKenzie, Moorman, \& Fetter, 1990).

As predicted, we also noted a negative effect of supervisor`s perceived subclinical psychopathy on normative and affective commitment, but discerned no significant correlation with continuance commitment. These findings support Hypothesis 1 . However, one of the dimensions of subclinical psychopathy attributed to leaders, boldness, had no significant effect on organizational commitment and the affective aspect of job satisfaction. It is also interesting to note the statistically significant positive correlation between bold supervisors and satisfaction with manager. Although these results seem to refute the hypothesizes, they may indicate that boldness reflects a "bright side" of industrial psychopaths. Boldness entails a capacity to remain calm and focused in situations involving pressure or threat, an ability to recover quickly from stressful events, high self-assurance and 
social efficacy, and a tolerance for unfamiliarity and danger (Patrick, 2009). In the organizational environment (e.g., during business negotiations), some level of leader`s hardiness and fearless social dominance can be positively evaluated.

On the other hand, the subordinates, supervisors and co-workers of organizational psychopaths can easily mistake psychopathic traits for specific leadership traits. For example, those traits that reflect a severe lack of human feelings or emotional poverty (lack of remorse and empathy) can be put into service by corporate psychopaths, where being "tough" or "strong" (making unpopular decisions) or "cool under fire" (not displaying emotions in the face of unpleasant circumstances) can work in their favor (Babiak, Neumann, \& Hare, 2010). As a result, boldness can be confused with resilience or hardiness. This issue could be further investigated.

Nevertheless, this study is not free of potential limitations. One concern is connected with the structure of the sample, in which women dominated (over $70 \%$ of respondents). We decided not to analyze sex differences in job satisfaction and organizational commitment, although the previous research suggested the moderating role of gender on work attitudes (Boles, Wood, \& Johnson, 2003; Jachnis, 2008). Also, the respondents worked in different branches of industry and held different positions, therefore it was difficult to conduct the analysis indicating differences in work attitudes between employees working in different sectors. It would be, however, interesting to investigate the effect of the additional, demographic variables (such as gender, tenure, age, education) on organizational commitment and job satisfaction. Moreover, Clive Boddy (2011) pointed out that the theory of corporate psychopath is relatively new and it still requires improvement and further research. Especially, research on leadership personality traits such as the Big Five factor would ensure a better understanding of the nature of subclinical psychopathy. It would be beneficial to examine whether the dark triad of personality (comprising supervisor`s Machiavellianism, subclinical psychopathy and subclinical narcissism) affects employees`work attitudes.

In conclusion, the present study constituted an attempt to examine the effects of supervisor`s subclinical psychopathy on organizational commitment, overall job satisfaction and, especially, satisfaction with manager. Our findings indicated some interesting topics for future research in the field of work and organizational psychology, including the relation between leader`s Machiavellianism, subclinical psychopathy, and subclinical narcissism with employee`s work attitudes. The regression and correlation analysis confirmed that supervisor`s subclinical psychopathy can be treated as one of the organizational antecedents of overall job satisfaction, satisfaction with manager and organizational commitment.

\section{REFERENCES}

Allen, N. J., \& Meyer, J. P. (1990). The measurement and antecedents of affective, continuance and normative commitment. Journal of Occupational Psychology, 63, 1-18.

Allen, N. J., \& Meyer, J. P. (1996). Affective, continuance, and normative commitment to the organization: An examination of construct validity. Journal of Vocational Behavior, 49, 252-276.

Allen, N. J., Irving, G. P, \& Meyer, J. P. (1998). Examination of the combined effects of work values and early work experiences on organizational commitment. Journal of Organizational Behavior, 19, 29-52. 
Babiak, P. (1995). When psychopaths go to work: a case study of an industrial psychopath. Applied Psychology, 44(2), 171-188.

Babiak, P. (2007). From darkness into the light: psychopathy in industrial and organizational psychology. In: A. I. Willis, H. Herve, J. Yuille (Eds.), The Psychopath: Theory, Research, and Practice (pp. 420-423). New Jersey: Lawrence Erlbaum Associates.

Babiak, P., Hare R. D. (2006). Snakes in suits. When psychopaths go to work. New York: Harper Collins.

Babiak, P., Neumann, C. S., \& Hare, R. D. (2010). Corporate psychopathy: talking the walk. Behavioral Sciences and the Law, 28, 174-193.

Bańka, A., Wołoska A., \& Bazińska R. (2002). Polska wersja Meyera i Allen Skali Przywiązania do Organizacji [Polish version the Meyer and Allen`s Organizational Commitment Scales]. Czasopismo Psychologiczne, 8(0), 65-74.

Boddy, C. (2010). Corporate psychopaths, bullying and unfair supervision in the workplace. Journal of Business Ethics, 100(3), 367-379.

Boddy, C. R. (2005). The implications of corporate psychopaths for business and society: an initial examination and a call to arms. Australasian Journal of Business and Behavioral Sciences, 1(2), 30-40.

Boddy, C. R. (2006) The dark side of management decisions: organisational psychopaths. Management Decision, 44(10), 1461 - 1475.

Boddy, C. R. (2011). The corporate psychopaths theory of the global financial crisis. Journal of Business Ethics, 102, 255-259.

Boddy, C. R. (2012). The impact of corporate psychopaths on corporate reputation and marketing. The Marketing Review, 12(1), 79-89(11).

Boddy, C. R., Ladyshewsky, R. K., \& Galvin, P. (2010). The influence of corporate psychopaths on Corporate Social Responsibility and organizational commitment to employees. Journal of Business Ethics, 97, 1-19.

Boddy, C., Ladyshewsky, R., \& Galvin P. (2010). Leaders without ethics in global business: corporate psychopaths. Journal of Public Affairs. Special Issue on Unethical Leadership, 10 (3), 121-138.

Boles, J. S., Wood, J. A., \& Johnson, J. (2003). Interrelationships of role conflict, role ambiguity, and work-family conflict facets of job satisfaction and the moderating effects of gender. Journal of Personal Selling and Sales Management, 23(2), 99 - 113.

Chodkiewicz, J. (2009). Adaptacja polska Kwestionariusza Zadowolenia z Życia (FLZ) [Polish adaptation of the Life Satisfaction Questionnaire (FLZ)]. Studia Psychologiczne [Psychological Studies], $47(3), 5-21$.

Cleckley, H. M. (1988). The Mask of Sanity. Saint Louis: C.V. Mosby Co.

Dirks, K. T., \& Ferrin, D. L. (2002). Trust in leadership: Meta-analytic findings and implications for research and practice. Journal of Applied Psychology, 87(4), 611-628.

Falkenbach, D., Poythress, N., \& Creevy, C. (2008). The exploration of subclinical psychopathic subtypes and the relationship with types of aggression. Personality and Individual Differences, 44(4), 821-832.

Gudmundsson, A., \& Southey, G. (2011) Leadership and the rise of the corporate psychopath: What can business schools do about the 'snakes inside'? e-Journal of Social \& Behavioural Research in Business, 2(2), 18-27.

Hall, J. R., \& Benning, S. D. (2006). The "successful" psychopath adaptive and subclinical manifestations of psychopathy in the general population. In: C. J. Patrick (Ed.), Handbook of Psychopathy, (pp. 459-480). New York: The Guilford Press.

Hare, R. (1999). Without Conscience: The Disturbing Word of the Psychopaths Among Us. New York: Guildford Press.

Hare, R. D. (2003). The Hare Psychopathy Checklist-Revised (PCL-R) (2nd ed.). Toronto: Multi-Health Systems.

Hare, R., \& Neumann, C. (2006). The PCL-R Assessment of Psychopathy Development, Structural Properties. In: C. J. Patrick (Ed.), Handbook of Psychopathy (pp.58-90). New York: Guilford Press.

Harris, G. T., Rice M. E., \& Quinsey V. L. (1994). Psychopathy as a taxon: evidence that psychopaths are a discrete class. Journal of Consulting and Clinical Psychology, 62(2), 387-397.

Jachnis, A. (2008). Psychologia organizacji. Kluczowe zagadnienia [Organizational psychology. Key issues]. Warszawa: Difin.

Judge, T. A., \& Klinger, R. (2007). Job satisfaction: Subjective well-being at work. In: M. Eid, R. Larsen (Eds.), The Science of Subjective Well-Being (pp. 393-413). New York: Guilford Publications. 
Kim, S. (2002). Participative Management and Job Satisfaction: Lessons for Management Leadership. Public Administration Review, 62(2), 231-241.

LeBreton, J. M., Binning, J. F., \& Adorno, A. J. (2006). Subclinical psychopaths. In: J. C. Thomas, D. L. Segal (Eds.), Comprehensive Handbook of Personality and Psychopathology. Volume 1. Personality and everyday functioning (pp. 388-411). New Jersey: John Wiley \& Sons.

Liden, R. C., Wayne, S. J., \& Sparrowe, R. T. (2000). An examination of the mediating role of psychological empowerment on the relations between the job, interpersonal relationships, and work outcomes. Journal of Applied Psychology, 85(3), 407-416.

Locke, E. A. (1976). The nature and causes of job satisfaction. In: M. D. Dunnette (Ed.), Handbook of industrial and organizational psychology (pp. 1297-1349). Chicago: Rand McNally.

Lok, P., \& Crawford, J. (1999). The relationship between commitment and organizational culture, subculture, leadership style and job satisfaction in organizational change and development. Leadership Organization Development Journal, 20(7), 365-374.

Lok, P., \& Crawford, J. (2001). Antecedents of organizational commitment and the mediating role of job satisfaction. Journal of Managerial Psychology, 16(8), 594 - 613.

Lok, P., Crawford, J. (2004). The effect of organisational culture and leadership style on job satisfaction and organisational commitment. A cross-national comparison. Journal of Management Development, 23(4), 321-338.

Madjar, N., Oldham, G., \& Pratt, M. (2002). There`s no place like home? The contributions of work and non-work creativity support to employees`creative performance. The Academy of Management Journal, 45(4), 757-767.

Madlock, P. E. (2008). The Link Between Leadership Style, Communicator Competence, and Employee Satisfaction. Journal of Business Communication, 45, 61-78.

Meyer, J. P., \& Allen, N. J. (1991). A three-component conceptualization of organizational commitment. Human Resource Management Review, 1(1), 61-89.

Meyer, J. P., Irving, G., \& Allen, N. J. (1998). Examination of the combined effects of work values and early work experiences on organizational commitment. Journal of Organizational Behavior, 19, 29-52.

Meyer, J. P., Stanley, D. J., Herscovitch, L., \& Topolnytsky, L. (2002). Affective, continuance, and normative commitment to the organization: a meta-analysis of antecedents, correlates, and consequences. Journal of Vocational Behavior, 61, 20-52.

Mullins-Sweatt, S., Glover, N., Derefinko, K., Miller, J., \& Widiger, T. (2010). The search for the successful psychopath. Journal of Research in Personality, 44, 554-558.

O'Driscoll, M. P., \& Randall, D. M. (1999). Perceived organisational support, satisfaction with rewards, and employee job involvement and organisational commitment. Applied Psychology: an Internetional Review, 48 (2), 197-209.

Patrick, C. J. (2006). Back to the Future. Cleckley as a Guide to the Next Generation of Psychopathy Research. In: C. J. Patrick (Ed.), Handbook of Psychopathy (pp. 605-618). New York: The Guilford Press.

Patrick, C. J. (2010). Operationalizing the triarchic conceptualization of psychopathy: Preliminary description of brief scales for assessment of boldness, meanness, and disinhibition. Unpublished manual, Department of Psychology, Florida State University, Tallahassee, FL. Retrieved from http:/ / www.phenxtoolkit.org.

Patrick, C. J., Fowles, D. C., \& Krueger, R. F. (2009). Triarchic conceptualization of psychopathy: developmental origins of disinhibition, boldness, and meanness. Development and Psychopathology, 21, 913-938.

Paulhus, D. L., \& Williams, K. M. (2002). The Dark Triad of personality: narcissism, Machiavellianism, and psychopathy. Journal of Research in Personality, 36, 556-563.

Pethman, T., \& Erlandssen, S. (2002). Aberrant self-promotion or subclinical psychopathy in a Swedish general population. The Psychological Record, 52, 33-50.

Podsakoff, P. M., MacKenzie, S. B., Moorman, R. H., \& Fetter, R. (1990). Transformational leader behaviors and their effects on followers ' trust in leader, satisfaction, and organizational citizenship behaviors. Leadership Quarterly, l(2), 107-142.

Saari, L. M., \& Judge, T. A. (2004). Employee attitudes and job satisfaction. Human Resource Management, 43(4), 395-407.

Sellbom, M., \& Phillips, T. R. (2012). An Examination of the Triarchic Conceptualization of Psychopathy in Incarcerated and Nonincarcerated Samples. Journal of Abnormal Psychology. DOI: 10.1037/ a0029306. 
Smith, S. F., \& Lilienfeld, S. O. (2013). Psychopathy in the workplace: The knowns and unknowns. Aggression and Violent Behavior, 18(2), 204-218.

Solinger, O. N., van Olffen, W., \& Roe, R. A. (2008). Beyond the Three-Component Model of Organizational Commitment. Journal of Applied Psychology, 93(1), 70-83.

Stanley, J. H., Wygant, D. B., \& Sellbom, M. (2012): Elaborating on the Construct Validity of the Triarchic Psychopathy Measure in a Criminal Offender Sample, Journal of Personality Assessment. DOI:1 0.1080/00223891.2012.735302.

Stevens, G. W., Deuling, J. K., \& Armenakis, A. A. (2011). Successful Psychopaths: Are They Unethical Decision-Makers and Why? Journal of Business Ethics, 1-11. Retrieved from http:/ / www.springerlink.com/content/4g885w8142011640/.

Waldman, I. D., \& Rhee, S. H. (2006). Genetic and Environmental Influences on Psychopathy and Antisocial Behavior. In: C. J. Patrick (Ed.), Handbook of Psychopathy (pp. 205-228). New York: Guilford Press.

Weiss, H. M. (2002). Deconstructing job satisfaction. Separating evaluations, beliefs and affective experiences. Human Resource Management Review, 12, 173-194.

Westerlaken, K. M., \& Woods, P. R. (2013). The relationship between psychopathy and the Full Range Leadership Model. Personality and Individual Differences, 54(1), 41-46.

Wu, W., \& Short, P. M. (1996). The relationship of empowerment to teacher job commitment and job satisfaction. Journal of Instructional Psychology, 23(1), 85-89.

Yousef, D. A. (2000). Organizational commitment: a mediator of the relationships of leadership behavior with job satisfaction and performance in a non-western country. Journal of Managerial Psychology, 15(1), $6-24$.

Zalewska, A. (2001). Arkusz Oceny Pracy O. Neubergera i M. Allerbeck - adaptacja do warunków polskich [Job Satisfaction Questionnaire by O. Neuberger and M. Allerbeck -adaptation to Polish conditions]. Studia Psychologiczne [Psychological Studies], 39(1), 197-217. 